\title{
Energy Sector Status and Hydropower Development in the Eastern Nile Basin
}

\author{
Habtamu Diriba ${ }^{1}$, Fengting $\mathbf{L i}^{2 *}$ \\ ${ }^{1}$ College of Environmental Science and Engineering, UNEP-Tongji Institute of Environment for Sustainable Development, Tongji \\ University, Shanghai, China \\ ${ }^{2}$ College of Environmental Science and Engineering, State Key Laboratory of Pollution Control and Resource Reuse Study, Tongji \\ University, Shanghai, China \\ Email: ^fengting@tongji.edu.cn, habtamu_diriba@yahoo.com
}

How to cite this paper: Diriba, H. and $\mathrm{Li}$, F.T. (2021) Energy Sector Status and Hydropower Development in the Eastern Nile Basin. Open Access Library Journal, 8: e7338.

https://doi.org/10.4236/oalib.1107338

Received: March 22, 2021

Accepted: April 4, 2021

Published: April 7, 2021

Copyright $\odot 2021$ by author(s) and Open Access Library Inc.

This work is licensed under the Creative Commons Attribution International License (CC BY 4.0).

http://creativecommons.org/licenses/by/4.0/

\begin{abstract}
Water has historically been used by humans for several purposes, such as power generation, domestic use, and irrigation. However, water management in the Nile Basin and, overall, in Africa faces social, technical, economic, political, and environmental challenges. Energy consumption levels are directly proportional to economic growth and development. The Nile Basin nations have an estimated 140,000 megawatts (MW) of hydropower potential, but a small fraction is exploited except for Egypt. Mainly, the Eastern Nile Basin has a vast resource for hydropower development. Nevertheless, currently, there is high political tension between the main riparian's nations (Egypt, Sudan, and Ethiopia) on the allocation of Blue Nile water originating from Ethiopia. The purpose of this paper is to assess an overview of energy status and hydropower development potentials for meeting basic energy needs in the Eastern Nile Basin by using different integrative literature review which summarizes past and present research works, drawing overall conclusions, highlighting unresolved issues, and then provide directions for future research. The finding shows that the Eastern Nile Basin energy sector is characterized by heavy dependency on hydro-electricity in Ethiopia, fuel fossils in Egypt, and minimal overall energy supplies in Sudan. Currently, Egypt, Sudan, and Ethiopia have produced $2800 \mathrm{MW}, 1591 \mathrm{MW}$, and $894 \mathrm{MW}$ hydropower from the Nile River and its tributaries respectively. In Sudan and Ethiopia, electrical connectivity remains very limited, resulting in a high overall dependent on biomass to meet basic energy needs. The Grand Ethiopian Renaissance Dam (GERD) designed to produce $6000 \mathrm{MW}$ of hydropower, however, would raise the existing supply of Ethiopian electricity by triple when completed. Besides, the energy power will be distributed to other East African nations to expand energy coverage. This review paper can be used as basic information for the Eastern Nile Basin government bodies, researchers, and different stakeholders.
\end{abstract}




\section{Subject Areas}

Hydrology

\section{Keywords}

Eastern Nile, Hydropower, Existing Dams, Energy Sector, Key Policies

\section{Introduction}

The Eastern Nile Basin, which spans three main riparian nations and covers an area of about $1,738,000 \mathrm{~km}^{2}$, is the Nile's largest sub-basin which includes Sudan, Egypt, and Ethiopia countries (Figure 1). The Blue Nile, White Nile, and the Main Nile are the basin's three major rivers [1]. The basin has a large amount of hydropower development [2]. The region also has extensive potential for renewable energy, especially wind and solar energy. In Ethiopia, hydropower capacity is significant, however, inadequate in Sudan and Egypt [3]. The basin riparian nations are currently working on several reservoir infrastructures to meet the region's food and energy production needs [4]. Today, more than 45,000 dams are installed on half of the world's major river basin and can accommodate about $15 \%$ of the international yearly surface overflow. Hydropower at present accounts for almost $16 \%$ of worldwide electrical energy production and around $70 \%$ of renewable electrical energy [5]. More than 3700 major dams with a power of as a minimum of one MW of hydropower are under a building or planned; these dams would help to the supply of electricity to a projected 840 million populations yet without access to electrical energy [6]. Dams in international river basins can, however, trigger conflict, as dams that control river flows in upstream nations can affect the water supplies in downstream nations [5].

For over 250 million people, the Upper Blue Nile Basin is taken as a lifeline and provides $\sim 50 \mathrm{Gm}^{3}$ /year of water to the River Nile [7]. The main riparian nations (Ethiopia, Egypt, and Sudan) energy sector is characterized by heavy dependency on hydro-electricity in Ethiopia, fuel fossils in Egypt, and limited

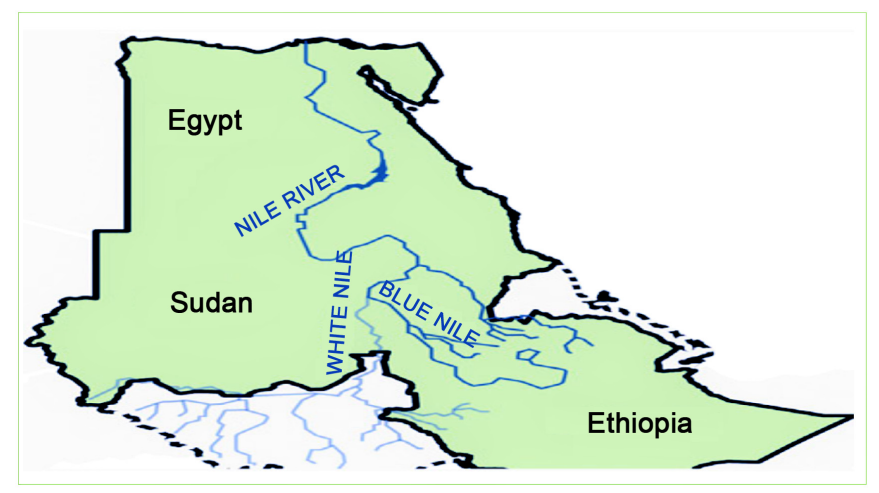

Figure 1. The eastern Nile Basin and the three countries where the river flows. 
overall energy capacity in Sudan [8]. Simultaneously, in Sudan and Ethiopia, electrical connectivity remains very limited, resulting in a general high dependency on biomass to meet basic energy needs [9]. Egypt's natural gas reserves are beneficial for energy generation, but the planned substitution of petroleum products would lead to a rapid decrease in reserves [10]. In Ethiopia, generating electricity for the national grid is generally almost entirely dependent on hydropower. In both Ethiopia and Sudan's urban and rural regions, there are major differences in the ratio of society who have access to electricity, with $42.9 \%$ and $38.5 \%$ of the total connected populations, respectively, in 2016. Given the disparities in energy sources and levels of access to electricity, trading in electricity may well be cost-effective and may also enhance regional cooperation in the situation of variability and climate change, which in particular affects the stability of hydropower generation [3]. This paper can be used as basic information to meet basic energy needs and to make decisions for the basin countries' governments.

\section{Water Resource Management and Energy Development in the Nile Basin}

Africa has many rivers running through eastern, western, central, and southern regions which providing great hydropower development opportunities [11]. In the continent, especially in Sub-Saharan Africa, there is huge hydropower potential that could be exploited. However, the water management system in Africa faces social, technical, economic, political, and environmental challenges to achieve sustainable water management. The hydropower resources in Sub-Saharan countries account for approximately $12 \%$ of the world's hydropower potential. However, only $17.6 \%$ of these resources have been harnessed which is one of the world's lowest figures [12]. The Nile Basin is politically full of tension, suspicion, mistrust, and diplomatic conflict between the North-Eastern African countries [13]. The basin was viewed as a source of conflict rather than cooperation for centuries [5].

Currently due to dramatic population increase and an immense rise in human activities, climatic change, and hydro-ecological degradation the demand for freshwater has increased which will aggravate regional tension over water in the world's disputed basin [14]. Besides, the basin nations have a severe energy shortage to improve the region's energy needs and Sustainable Development Goals [15]. The main energy challenges faced by the sub-region and Africa as a whole are low-level energy access, heavy dependence on biomass for energy, low per capita consumption, lack of resources management, and lack of energy infrastructure [16]. To achieve these goals, there should be effective governance of the resources with improved institutional performance within the region. More deliberative water governance is, thus, needed for informed transboundary water and energy utilization [12].

Given the increasing demand for clean, reliable, and affordable energy, the 
role of hydropower is gaining importance, particularly as a means to reduce poverty and attain sustainable development [17]. Hydropower can be used not only to provide electricity access but can also effectively contribute to regional cooperation and development through the judicious and optimally allocating increasingly limited sources of energy. Besides, hydropower has a significant role to play in the solution of Africa's energy security and addressing economic, social, and environmental issues [11]. The Nile water is enough for all if riparian states are managed and used sustainably in the future.

\section{The Eastern Nile Basin}

The Nile Basin has two major basins. These are the Eastern Nile Basin that includes the Blue Nile also called Abbay River in Ethiopia (59\%), Sobat (Baro-Akobo) (14\%), and Tekeze (Atbara) (13\%) those totally $86 \%$ generating from Ethiopia, and the Equatorial Lake Basin (14\%) from Central and Eastern Africa [18]. The Blue Nile contributes most water of the Nile River [10]. All of the Blue Nile's tributaries originating from Ethiopia's highlands [18]. Ethiopia and Sudan share a border. However, Ethiopia and Egypt don't share a border, the Nile's ecological relationship has for worse or better, connected the two states intricately. The four months (June-September) of wet season precipitation in Ethiopia generates over $70 \%$ of the Blue Nile flow. The yearly average precipitation over the Blue Nile is $400 \times 10^{9} \mathrm{~m}^{3} /$ year, $62.5 \%$ which falls from the plateau of Ethiopia [19]. The Blue Nile is characterized by extremely vigorous topography and large altitude variations. The basin's total area is $311,437 \mathrm{~km}^{2}$, with Ethiopia accounting for $63 \%$ and Sudan for $37 \%$. The basin's altitude varies greatly, from over $4000 \mathrm{~m}$ in some tributary headwaters to $700 \mathrm{~m}$ at the plateau's base. The highest mountain in Lake Tana is around $1800 \mathrm{~m}$, and the river reaches Sudan at a height of $490 \mathrm{~m}$ at the national border, an elevation of around $1.5 \mathrm{~m} / \mathrm{km}$. This makes the Blue Nile its distinctive attribute of the massive potential energy opportunity in the Eastern Nile to growing hydropower [18]. At the time of writing this paper, there is no cooperation between Sudan, Ethiopia, and Egypt to use Blue Nile River. Egypt and Sudan instead of agreeing to use the resources with Ethiopia appeal to different international organizations. Future agreement on how to use the water in a win-win situation is a way forward in the region.

\section{The Eastern Nile Basin Energy Sector Status and Key Energy Policies}

\subsection{Ethiopia}

Ethiopia enjoys multiple renewable resources and has 124 billion cubic meters (BCM) of river water, $30 \mathrm{BCM}$ groundwater, and $70 \mathrm{BCM}$ lake water resources [20]. The national supply of electricity in Ethiopia depends completely on hydropower. Currently, the country has around $4500 \mathrm{MW}$ of installed generation capacity. Approximately $90 \%$ of the installed generation capacity is from hydropower, while the remaining wind, diesel, and the shares of geothermal energy 
were, $7.7 \%, 2.1 \%$, and $0.2 \%$ respectively. The overall consumption of electricity was 6.7 Terawatt Hours (TWh) in 2014, up from 2.4 TWh in 2006 and 3.8 TWh in 2011 [21]. In Ethiopia, only 57\% of households have access to as a minimum one power source (33.1\% grid and $23.9 \%$ off-grid) [22], there was a major difference between rural and urban areas; the latter was connected to just around $5 \%$ of the populations [23], although $87 \%$ of urban populations were connected, the industry remains a small user of electricity [8].

About three-quarters of the Ethiopian rural population relies heavily on conventional biomass for heating and cooking. As a consequence, biomass remains Ethiopia's primary energy source, accounted for $91 \%$ of the consumed energy in 2015 [3]. Around 7\% of overall main energy is generated by petroleum, and electrical energy accounts for just $2 \%$ of total energy consumption [24]. Biomass use in the housing area accounts for more than $98 \%$ of the total supply [25]. Ethiopia has a lot of potential for renewable energy [26]. Hydropower has a 45 Gigawatts $(\mathrm{GW})$ potential, the wind has a $10 \mathrm{GW}$ potential, and geothermal has a $5 \mathrm{GW}$ potential. Fossil fuel reserves are also significant [27]. The natural gas reserve is around 4 trillion cubic feet, and the coal reserve is projected to be over 300 million tons. While these local resources are not currently used for power generation, the government is interested to explore these resources soon [28].

\subsection{Egypt}

Egypt is one of the driest nations in the world. The Nile provides more than $97 \%$ of Egypt's clean water supply to its 100 million citizens. With over 4.5 billion barrels of oil reserves, Egypt is the world's $25^{\text {th }}$ most oil-producing nation [29]. However, the oil reserves of the country have decreased significantly, and by 2030 it is expected that only around 1.5 billion barrels of oil will be left [3]. The country also has important natural gas reserves, which presently the dominant power generation in Egypt. While power generation has significantly increased in Egypt, growth has not been sufficient to meet the increasingly growing demand for energy. Electrical energy production grew at a $5.8 \%$ annual rate from 95 TWh in 2004 to 131 TWh in 2010 and 168 TWh in 2014 [30]. From 23.5 GW in 2009 to $32 \mathrm{GW}$ in 2014, the capacity of installed power generation has increased [3]. Electricity consumption on the national grid grew dramatically from 64.3 TWh in 2001 to 147.5 TWh in 2014, a 6.5\% annual increase [31]. The administration has as well started initiatives to inspire renewable energy technology for energy production. Due to decreased potential and stagnation at $2.8 \mathrm{GW}$, hydropower dimensions have not improved in current years [3].

\subsection{Sudan}

Most of Sudan's land is also either arid or semi-arid as opposed to that of the lands of Ethiopia. Sudan faces the dual problems of inadequate access to contemporary energy and heavy dependency on conventional sources of biomass to meet its increasingly rising demands for energy [3]. Charcoal and fuelwood ac- 
count for about 75\% of the population's energy needs, particularly in rural regions [32]. As a consequence of the division of Sudan into two countries (Sudan and South Sudan) crude oil production decreased from 8380 kilotons in 2000 to 6950 kilotons in 2015. In 2016, 39\% of the societies were connected to the national grid. The rate of electricity access is $62 \%$ higher in urban areas, but about $22 \%$ lesser in rural regions in 2016 (up from 18\% in 2014) [3]. Power generation depends primarily on hydropower, which accounts for $75 \%$ of total output and has a capacity of $4176 \mathrm{MW}$. Hydropower and thermal power plants have a combined installed capacity of $1591 \mathrm{MW}$ and $1400 \mathrm{MW}$, correspondingly. The overall generation of electricity rose from 4125 Gigawatt hours (GWh) in 2005 to $11,848 \mathrm{GWh}$ in 2014. In 2014, Sudan imports approximately $4 \%$ of its electricity. Electricity feeding per person in 2014 was 140-kilowatt hours (kWh), far below the African average of $500 \mathrm{kWh}$ [33]. Renewable energy can perform a substantial role in increasing modern energy access in Sudan, improving energy security, and contributing to global climate mitigation. The administration needs to incorporate renewable energy into the power system, with a goal of $20 \%$ by 2030 [34].

\subsection{The Eastern Nile Basin Key Energy Policies}

Egypt is among the largest energy producers and suppliers in Africa. It is one of the $3^{\text {rd }}$ most populated countries on the African continent next to Nigeria and Ethiopia, which leads to its energy needs increasing. In more recent years, due to energy blackouts, the Egyptian government set a plan to diversify and invest more in the sector. The Ministry of Planning, Monitoring, and Administrative Reform published the "Sustainable Development Strategy: Egypt Vision 2030", Egypt's first participatory long-term strategy document [35]. Energy is ranked as the second critically significant foundation for sustainable development in Egypt's Vision 2030 [36]. The vision report highlights the optimal use of domestic energy sources in addition to the asset allocation of the total energy mix to include alternative energy sources for power generation, such as renewable energy. Egypt Vision 2030 and the Ministry of Electricity and Renewable Energy have established a minimum goal of generating $20 \%$ of overall electricity from renewable sources by 2020 [3]. Furthermore, Egypt's Nationally Defined Commitment (NDC) emphasizes Carbon dioxide emissions reduction in the energy sector along with the promotion of clean energy-generation technologies [37].

Ethiopia is the $2^{\text {nd }}$ most populated country in Africa next to Nigeria which leads to its energy needs increasing. As mentioned above, Ethiopia's power production is currently heavily dependent on hydropower; plans to raise capacity to 13.5 GW by 2040 will make Ethiopia Africa's second-largest hydro producer. The Ethiopian government's 15-year National Growth and Transformation Plan (GTP) targets to double the percentage of the population who has access to electricity [38], as well as improve large-scale hydropower initiatives to increase the supply of other energy sources [39]. To meet the expected rise in electricity demand as a result of the country's rapid economic development, the Ethiopia 
Electric Power Corporation (EEPC) aims to incorporate alternative power plants interested in the energy sector, including wind, geothermal, solar, fuel-oil, and gas-based plants [40]. Additionally, the EEPC intends to export energy to neighboring nations. Installed capacity achieved 4206 MW under GTP I (2010-2015) [38], while GTP II (2016-2020) aims to build 14,561 MW of generation projects, but not achieved [41]. Currently, the country has about $4500 \mathrm{MW}$ of installed generation capacity. Ethiopia initiated the "Light to All" in November 2017, the National Electrification Program was initiated, to supply electricity to all Ethiopians by 2025 [3]. The Ethiopian NDC is focused on the Climate Resilient Green Economy Strategy, and in comparison to baseline levels, it aims to reduce GHG emissions by $64 \%$ by 2030 [38].

Sudan is challenged with numerous energy development problems, including high electricity subsidies and climate-related impacts on hydroelectric generation, which has been declining at a rate of about $4 \%$ annually. Sudan's development goal is to improve access to new and affordable energy. Sudan's government intends to incorporate clean energy technology into the energy sector, with a $20 \%$ renewable energy commitment by 2030 [36]. Utilizing Sudan's renewable energy potential for making electricity accessible throughout the country; producing competitive prices energy from renewable sources, and diversifying energy supply sources to guarantee energy protection are all key government strategies for power sector growth [3], help the national economy by transferring technologies and expertise, building power, and supporting the local renewable energy industry; and provide access to electric energy supply to rural areas far from national or decentralized grids, for which power grid is not a feasible option [42]. The three countries belong to the Eastern Africa Power Pool, which aims to secure energy supply, optimal use of energy resources, provide affordable electricity prices through grid interconnection, and develop a competitive electricity market in the basin [3]. Table 1 shows the summary of present and planned power plants and their capacity (GW) by country.

Table 1. Summary of present and planned power plants and their capacity (GW) by country.

\begin{tabular}{lcccccc}
\hline \multirow{2}{*}{ Description } & \multicolumn{2}{c}{ Existing capacity $(\mathrm{GW})$} & \multicolumn{2}{c}{ Planned capacity $(2015-2020)(\mathrm{GW})$} \\
\cline { 2 - 6 } & Egypt & Ethiopia & Sudan & Egypt & Ethiopia & Sudan \\
\hline Combined cycle (dual fired) & 11.33 & - & 0.36 & 9.2 & - & - \\
Steam turbine (dual fired) & 16.89 & - & 0.18 & 1.3 & - & - \\
Diesel simple cycle & 0.31 & 0.089 & 0.05 & - & - & 0.656 \\
Heavy fuel oil steam turbine & 0.09 & - & 0.81 & - & - & 0.9 \\
Biomass based plant & - & - & - & - & 0.136 & - \\
Hydro & 2.8 & 4.5 & 1.585 & - & 0.639 & 0.42 \\
Concentrated solar power & - & - & - & 0.24 & - & - \\
Wind & 0.55 & 0.324 & - & 1.34 & 0.12 & - \\
Solar PV & 0.14 & - & - & 0.24 & - & - \\
Geothermal & - & 0.007 & - & - & - & - \\
\hline
\end{tabular}

Source: Alam Hossain Mondal (2020); Azer. T (2014); Rabah. A (2016). 


\section{Existing and Proposed Hydropower Projects in the Eastern Nile Basin}

As discussed above, water management in the Nile Basin and Africa in general faces environmental, social, technical, economic, and political challenges [43]. Power shortages are a factor in reducing growth and rising food shortages. The Nile Basin nations have an approximate hydropower capacity of 140,000 MW, but except for Egypt, a limited fraction is exploited. The Democratic Republic of Congo (DRC) alone is thought to have a 100,000 MW potential. Ethiopia has a hydropower potential of 45,000 MW. However, in terms of installed capacity, Egypt with the Aswan Dam leads with $2800 \mathrm{MW}$, followed by the DRC (2440 MW), and Mozambique (not basin country) (2180 MW) [44]. Demand for water and power is growing in the basin nations as the population increases. Presently, the Eastern Nile hydro-system contains eight major hydraulic infrastructures in operation and some four proposed hydropower plants in Ethiopia [18], mentioned in Table 2 and Table 3.

Table 2. Major eastern Nile basin dams for hydropower development.

\begin{tabular}{|c|c|c|c|c|c|c|c|c|}
\hline Description & $\begin{array}{c}\text { Aswan } \\
\text { High Dam }\end{array}$ & Merowe & Jebel Aulia & $\begin{array}{c}\text { Aswan Old } \\
\text { Dam }\end{array}$ & Roseires & $\begin{array}{l}\text { Khasm } \\
\text { el-Girba }\end{array}$ & GERD & Tekeze Dam \\
\hline Nile tributary & Main Nile & Main Nile & White Nile & Main Nile & Blue Nile & Atbara & Blue Nile & Tekeze \\
\hline Country & Egypt & Sudan & Sudan & Egypt & Sudan & Sudan & Ethiopia & Ethiopia \\
\hline Year of started & 1960 & 2004 & 1933 & 1898 & 1961 & 1960 & 2011 & 1999 \\
\hline Year of completed & 1971 & 2009 & 1937 & 1902 & 1966 & 1964 & $77 \%(2020)$ & 2009 \\
\hline Total storage & $163 \mathrm{BCM}$ & $12.1 \mathrm{BCM}$ & $3.3 \mathrm{BCM}$ & N.A. & $5.5 \mathrm{~b} \mathrm{BCM}$ & $1.3 \mathrm{BCM}$ & $74 \mathrm{BCM}$ & $4 \mathrm{BCM}$ \\
\hline Initial live storage & $137 \mathrm{BCM}$ & $5.7 \mathrm{BCM}$ & $2.8 \mathrm{BCM}$ & $5.3 \mathrm{BCM}$ & $5.4 \mathrm{BCM}$ & $1.2 \mathrm{BCM}$ & $31 \mathrm{BCM}$ & $9.3 \mathrm{BCM}$ \\
\hline $\begin{array}{c}\text { Installed } \\
\text { hydropower }\end{array}$ & $2100 \mathrm{MW}$ & $1250 \mathrm{MW}$ & $30 \mathrm{MW}$ & $592 \mathrm{MW}$ & $400 \mathrm{MW}$ & $10 \mathrm{MW}$ & $6000 \mathrm{MW}$ & $300 \mathrm{MW}$ \\
\hline
\end{tabular}

Source: Whittington; Waterbury (2014); Zedan (2014), and edited by authors.

Table 3. Proposed hydropower plants (installed and target power in megawatts (MW) and tailwater in meters above sea level (m.a.s.l) in Ethiopia.

\begin{tabular}{|c|c|c|c|c|c|}
\hline \multirow{2}{*}{$\begin{array}{l}\text { Hydropower } \\
\text { plant }\end{array}$} & \multicolumn{2}{|c|}{ Hydropower (MW) } & \multirow{2}{*}{ Tail water level (m.a.s.l) } & \multirow{2}{*}{$\begin{array}{c}\text { Country } \\
\text { (location) }\end{array}$} & \multirow{2}{*}{ Remarks } \\
\hline & Installed capacity & Target power & & & \\
\hline Karadobi & 1600 & 933 & 890 & Ethiopia & Understudy \\
\hline Bekoabo & 1940 & 1329 & 800 & Ethiopia & Understudy \\
\hline Upper Mendia & 1700 & 802 & 640 & Ethiopia & Understudy \\
\hline Bekoabo Low & 935 & 514 & 603 & Ethiopia & Understudy \\
\hline
\end{tabular}

Source: Asegdew G. Mulat (2018) and edited by authors.

\subsection{Ethiopia's Existing and Proposed Major Hydropower Plants}

The first is the Chara Chara weir, which regulates Lake Tana outflows to the Tis Abbay power complex, which is $32 \mathrm{~km}$ downstream of Lake Tana [45]. Lake 
Tana is a natural lake that regulates the flows of the Tana sub-basin [18]. Then, the Tana-Bales scheme (started operation in May 2010) consists of an artificial link between the Lake Tana and the Bales river to produce $460 \mathrm{MW}$ hydroelectric [45]. The building of Tana Bales hydropower is started in 2005 and was finished in May 2010, the project directly diverts water from Lake Tana and is presented in the models as such [18]. The other is the Tekeze Dam in Northern Ethiopia, which is a double-curved arch dam on the Tekeze River, a Nile tributary that flows downstream near Khartoum and joins the main Nile through the deepest canyons. The main goal of this reservoir's operation is to generate 300 MW of power generation [5]. The third is the GERD which is about $750 \mathrm{~km}$ North-West of Addis Ababa and $45 \mathrm{~km}$ from the Sudan border on the Blue Nile River in a place called Guba [46]. The construction was started in 2011, and when finished, currently (79\% completed) the GERD will become Africa's largest hydropower plant and the $8^{\text {th }}$ largest global hydropower plant [46]. The ultimate location for the GERD was discovered during a Blue Nile investigation directed from 1956 to 1964 by the U.S. Office of Reclamation [18]. This ambitious project is projected to generate over $6000 \mathrm{MW}$ of electricity. It will make a lake with a volume of more than 74 BCM, with an approximate cost of almost \$5 billion which is covered by the Ethiopian government [47]. Domestic and regional electrification is the primary aim of this dam and it is projected to boost access to electricity in East Africa through current and scheduled power connectors [5]. The cumulative energy generation in the Eastern Nile would grow due to GERD being in operation [1]. The scheme, however, is troubled by technological and financial issues, as well as resistance from its downstream nations [48]. Today, cooperation between the main riparian states (Egypt, Ethiopia, and Sudan) is becoming more serious than ever in resolving emerging conflicts over the construction and filling of the GERD. The talks among three nations with the government of the U.S. and the World Bank as observers in Washington between November 2019 and February 2020 failed to reach an agreement. Further talks among three nations were held by the African Union in July 2020 to reach a final treaty underscored that "African issues must be given African solutions" [5]. When this article was written, no treaty has been reached, the discussion is sometimes on-again and off-again. The Ethiopian government has also a plan to build further hydropower plant to meet energy needs on the Nile River tributaries (Table 3). However, the GERD situation is an example from which lessons can be learned in the politically sensitive and disputed river basins for future dam construction.

\subsection{Sudan's Major Hydropower Plants}

The first is the Jebel Aulia Dam, $40 \mathrm{~km}$ upstream of Khartoum on the White Nile River, which was built in 1937 to hold water for well along utilizing in Egypt. The rapid siltation of this reservoir, as well as the construction of the High Aswan Dam in Egypt in 1965, put an end to its operation of 30 MW [49]. The other 
is the Roseires Dam that was constructed in 1966, with an initial capacity of $3.024 \times 10^{9} \mathrm{~m}^{3}$ at $480 \mathrm{~m}$ level [18]. The key goal is to provide irrigation requirements as a priority and the second priority is the generation of $280 \mathrm{MW}$ hydropower [48]. The Khashm El Girba Dam was built just downstream of the Tekeze River. The dam was built to produce hydropower of $10 \mathrm{MW}$ [18]. The Merowe Dam was Sudan's largest dam recently built to fulfill the primary objective of producing hydropower. The power generation goal is a capacity of $1250 \mathrm{MW}$. A regulation was used to achieve this procedure that requires a turbine's discharge to achieve the energy generation target, accompanied by a flood prevention regulation which drops any water above a defined elevation [42].

\subsection{Egypt's Major Hydropower Plants}

The Aswan Old Dam, completed in 1902 and heightened in 1936, is the Nile River's first dam [48]. The targeted power generation was a capacity of $592 \mathrm{MW}$. The other is the Aswan High Dam reservoir, which extends $500 \mathrm{~km}$ along the Nile River and occupies $6000 \mathrm{~km}^{2}$, two-thirds of which is in Egypt (recognized as Lake Nasser) and one-third in Sudan (known as Lake Nubia) [18]. The dam, which was built in 1971 and is located $7 \mathrm{~km}$ south of Aswan City, is $2325 \mathrm{~m}$ long, $11 \mathrm{~m}$ high above the original riverbed, and 40 and $980 \mathrm{~m}$ wide at the crest and bottom, respectively [49]. The total reservoir capacity $\left(162 \times 10^{9} \mathrm{~m}^{3}\right)$ comprises of the dead storage of $31.6 \times 10^{9} \mathrm{~m}^{3}$ (147 meters above sea level (m.a.s.l.) of Lake water level), the effective reservoirs of $90.7 \mathrm{~km}^{3}$ (147 - 174 m.a.s.l), and the storage emergency for control of flood $41 \times 10^{9} \mathrm{~m}^{3}$ (175 - 182 m.a.s.l) [18]. There is rugged desert terrain surrounding the reservoir. To the West is the vast Sahara Desert, and to the East in the Eastern Desert, which extends to the Red Sea. By providing irrigation water, the Aswan High Dam made a major contribution to Egypt's economic growth and approximately $2100 \mathrm{MW}$ of hydroelectricity, as well as shielding the lower reaches of the Nile from coastal flooding [50]. Table 4 compares the Nile River's biggest dam with the world's largest dam.

Table 4. Comparison of GERD and AHD with other hydropower projects of global significance.

\begin{tabular}{cccccc}
\hline Description & $\begin{array}{c}\text { Three Gorges } \\
\text { (China) }\end{array}$ & $\begin{array}{c}\text { Itaipu } \\
\text { (Brazil) }\end{array}$ & $\begin{array}{c}\text { Nam Theun } \\
\text { II (Laos) }\end{array}$ & $\begin{array}{c}\text { AHD } \\
\text { (Egypt) }\end{array}$ & $\begin{array}{c}\text { GRD } \\
\text { (Ethiopia) }\end{array}$ \\
\hline Dam height (m) & 101 & 225 & 39 & 110 & 145 \\
Annual flow (BCM) & 451 & 368 & 8 & 65 & 6000 \\
$\begin{array}{c}\text { Installed capacity (MW) } \\
\text { Total storage volume } \\
\text { (BCM) }\end{array}$ & 22,500 & 14,000 & 1070 & 2100 & 74 \\
People displaced & 39 & 29 & 7 & 163 & 14,000 \\
\hline
\end{tabular}

Source: Dale Whittington (2014); Asegdew G. Mulat (2018). 


\section{Conclusion}

This study aims to assess the existing status of the energy sector and hydropower production in the Eastern Nile Basin. Due to population increase and economic development energy use is growing rapidly in Eastern Nile Basin. Connection to sustainable sources of energy is important for economic growth and better living standards. The area of the Eastern Nile Basin has considerable renewable energy potential, especially wind and solar. Hydropower potential is huge in Ethiopia, but it is constrained in Sudan and Egypt. The extension of renewable energy sources including hydropower would help expand access to grid electricity while also promoting renewable energy protection, and climate change is reducing the instability of hydropower production. The Eastern Nile Basin energy sector is characterized by heavy dependency on hydro-electricity in Ethiopia, fuel fossils in Egypt, and minimal overall energy supplies in Sudan. Ethiopia's and Sudan's energy industry faces both the challenges of restricted modern energy services and a strong dependence on conventional biomass energy sources to meet their rising energy demands. In more recent years, due to energy blackouts, the basin governments set a plan to diversify and invest more in the energy sector. To increase the energy sector in the Eastern Nile Basin cooperation on how to allocate the existing resource is the way forward.

\section{Acknowledgements}

We would like to thanks the China Ministry of Commerce (MOFCOM) for financial support through a study of scholarship for the first author, UNEPTongji Institute of Environment for Sustainable Development (IESD), and Tongji University College of Environmental Science and Engineering, who gave me the golden opportunity to do this Article on the topic "Energy sector status and hydropower development in the Eastern Nile Basin".

\section{Conflicts of Interest}

The authors declare no conflicts of interest regarding the publication of this paper.

\section{References}

[1] Digna, R.F., Castro-Gama, M.E., Van der Zaag, P., Mohamed, Y.A., Corzo, G. and Uhlenbrook, S. (2018) The Use of a Genetic Algorithm to Optimize the Activity of the Eastern Nile System, as Well as the Distribution of Water Resources Growth Benefits. Water, 10, Article No. 921. https://doi.org/10.3390/w10070921

[2] Waterbury, J. (2008) The Nile Basin: National Determinants of Collective Action. Yale University Press, New Haven.

[3] Mondal, M.A.H. and Ringler, C. (2020) Long-Term Planning for Regional Power Sector Development: Cooperation Opportunities in the Eastern Nile? Energy, 201, Article ID: 117703. https://doi.org/10.1016/j.energy.2020.117703

[4] Jeuland, M., Wu, X. and Whittington, D. (2017) Infrastructure Development and the Economics of Cooperation in the Eastern Nile. Water International, 42, 
121-141. https://doi.org/10.1080/02508060.2017.1278577

[5] Basheer, M., et al. (2020) Filling Africa’s Largest Hydropower Dam Should Consider Engineering Realities. One Earth, 3, 277-281.

https://doi.org/10.1016/j.oneear.2020.08.015

[6] Abera, F.F., Asfaw, D.H., Engida, A.N. and Melesse, A.M. (2018) Optimal Operation of Hydropower Reservoirs under Climate Change: The Case of Tekeze Reservoir, Eastern Nile. Water, 10, Article No. 273. https://doi.org/10.3390/w10030273

[7] Dile, Y.T., Tekleab, S., Ayana, E.K., Gebrehiwot, S.G., Worqlul, A.W., Bayabil, H.K., et al. (2018) Advances in Water Management Research in the Upper Blue Nile and Their Implications for the Future: A Review. Journal of Hydrology, 560, 407-423. https://doi.org/10.1016/j.jhydrol.2018.03.042

[8] Demissie, A.A. and Solomon, A. (2016) Power System Sensitivity to Extreme Hydrological Conditions as Studied Using an Integrated Reservoir and Power System Dispatch Model, the Case of Ethiopia. Applied Energy, 182, 442-463. https://doi.org/10.1016/j.apenergy.2016.08.106

[9] Arjoon, D., Mohamed, Y., Goor, Q. and Tilmant, A. (2014) Hydro-Economic Risk Assessment in the Eastern Nile River Basin. Water Resources and Economics, 8, 16-31. https://doi.org/10.1016/j.wre.2014.10.004

[10] Sutcliffe, J. and Parks, Y.P. (1999) The Hydrology of the Nile. IAHS Special Publication No. 5, International Association of Hydrological Sciences, Wallingford.

[11] Kitaw, M. and Yitayew, M. (2014) Water Governance in the Nile Basin for Hydropower Development. In: Melesse, A., Abtew, W. and Setegn, S., Eds., Nile River Basin, Springer, Cham, 499-515. https://doi.org/10.1007/978-3-319-02720-3_25

[12] Abtew, W. and Melesse, A.M. (2014) The Nile River Basin. In: Melesse, A., Abtew, W. and Setegn, S., Eds., Nile River Basin, Springer, Cham, 7-21. https://doi.org/10.1007/978-3-319-02720-3_2

[13] Abawari, Y.M. (2011) Conflict and Cooperation among the Nile Basin Countries with Special Emphasis on the Nile Basin Initiative (NBI). International Institute of Social Studies, The Hague.

[14] Yitayew, M. and Melesse, A.M. (2011) Critical Water Resources Issues in the Nile River Basin. In: Melesse, A., Abtew, W. and Setegn, S., Eds., Nile River Basin, Springer, Dordrecht, 401-416. https://doi.org/10.1007/978-94-007-0689-7_20

[15] Kranz, N. and Mostert, E. (2010) Governance in Transboundary Basins-The Roles of Stakeholders; Concepts and Approaches in International River Basins. Earthscan, London, 91-106.

[16] Sinnona, G. (2012) Two-Tier Water Governance in the Nile River Basin.

[17] Degefu, D.M., He, W. and Zhao, J.H. (2015) Hydropower for Sustainable Water and Energy Development in Ethiopia. Sustain. Sustainable Water Resources Management, 1, 305-314.

[18] Mulat, A.G., Moges, S.A. and Moges, M.A. (2018) The Construction of Multi-Storage Hydropower in the Upper Blue Nile River Is Being Assessed (Ethiopia): Regional Perspective. Journal of Hydrology, 16, 1-14. https://doi.org/10.1016/j.ejrh.2018.02.006

[19] Mageed, Y.A. (1994) The Nile Basin: Lessons from the Past. Oxford University Press, New York.

[20] Oestigaard, T. (2010) Nile Issues: Small Streams from the Nile Basin Research Programme. Fountain Publishers, Kampala.

[21] Mondal, M.A.H., Bryan, E., Ringler, C., Mekonnen, D. and Rosegrant, M. (2018) 
Ethiopia's Energy Situation and Demand Scenarios: Opportunities to Boost Energy Quality and Reduce Greenhouse Gas Emissions. Energy, 149, 161-172. https://doi.org/10.1016/j.energy.2018.02.067

[22] Padam, G., Rysankova, D., Portale, E., Koo, B.B., Keller, S. and Fleurantin, G. (2018) Ethiopia-Beyond Connections: A Multi-Tier Framework-Based Energy Access Diagnostic Study. World Bank, Washington DC.

[23] Gebrehiwot, K., Alam Hossain Mondal, M., Ringler, C. and Getaneh Gebremeskel, A. (2019) Hybrid Power System Optimization and Cost-Benefit Analysis for Off-Grid Rural Electrification in Ethiopia. Energy, 177, 234-246. https://doi.org/10.1016/j.energy.2019.04.095

[24] Guta, F., Damte, A. and Rede, T.F.J.N.A. (2015) Ethiopian Residential Electricity Demand. Environment for Development (EfD): Discussion Paper Series, Ethiopia, 38.

[25] Tessema, Z., Mainali, B. and Silveira, S. (2014) Mainstreaming and Sector-Wide Approaches to Sustainable Energy Access in Ethiopia. Energy Strategy Reviews, 2, 313-322. https://doi.org/10.1016/j.esr.2013.11.003

[26] Tucho, G.T., Weesie, P.D.M. and Nonhebel, S. (2014) Assessment of Renewable Energy Resources Potential for Large Scale and Standalone Applications in Ethiopia. Renewable and Sustainable Energy Reviews, 40, 422-431. https://doi.org/10.1016/j.rser.2014.07.167

[27] Mengistu, M., Simane, B., Eshete, G. and Workneh, T.S. (2015) A Review on Biogas Technology and Its Contributions to Sustainable Rural Livelihood in Ethiopia. Renewable and Sustainable Energy Reviews, 48, 306-316. https://doi.org/10.1016/j.rser.2015.04.026

[28] Mondal, M.A.H., Bryan, E., Ringler, C. and Rosegrant, M. (2017) Ethiopian Power Sector Development: Universal Access to Renewable Energy and Export Strategies. Renewable and Sustainable Energy Reviews, 75, 11-20. https://doi.org/10.1016/j.rser.2016.10.041

[29] U.S. Energy Information Administration (2015) Egypt International Energy Data and Analysis. U.S. Energy Information Administration, Washington DC.

[30] CAPMS Statistical Yearbook-Industry \& Petroleum; September Issue (2015) Egypt: Central Agency for Public Mobilization and Statistics (CAPMS).

[31] Azer, T. (2014) Use of Energy in Egypt, Past and Recent. In: 9th Oslo Group Meeting, Abu Dhabi, 1-50.

[32] UN Environment Programme (2017) Atlas of Africa Energy Resources.UN Environment Programme, Nairobi.

[33] Rabah, A.A., Nimer, H.B., Doud, K.R. and Ahmed, Q.A. (2016) Modelling of Sudan's Energy Supply, Transformation, and Demand. Energy, 2016, Article ID: 5082678. https://doi.org/10.1155/2016/5082678

[34] Northrop, E., et al. (2016) Examining the Compatibility of the Planned Nationally Defined Commitments with the Priorities of SDGs. World Resources Institute, Washington DC.

[35] Ebner, P., Ghimire, R. and Saleh, W.D. (2020) Employability of Egyptian Agriculture University Graduates: Skills Gaps. Journal of International Agricultural and Extension Education, 27, 128-143. https://doi.org/10.5191//jiaee.2020.274128

[36] El-Khadrawy, R.K., et al. (2020) Environmental Science and Sustainable Development.

[37] EEHP (2015) Annual Report of Egyptian Electricity Holding Company (EEHP): 
Ministry of Electricity \& Renewable Energy, Arab Republic of Egypt.

[38] Seboka, M.D. (2017) Ethiopian Energy Status, Challenges, and Opportunities. In: Presented at a Stakeholders Workshop on Alternative Pathways to Improve Electricity Access in Ethiopia, November 28, 2017, Addis Ababa, 5-12.

[39] Ministry of Finance and Economic Development (2010) Growth and Transformation Plan (2010/11-2014/15). Ministry of Finance and Economic Development (MoFED), Addis Ababa.

[40] FDRE, Ministry of Finance Economic Development (2014) Growth, and Transformation Plan: Annual Progress Report for FY 2012/13.

[41] NPC (2016) Growth and Transformation Plan II (GTP II) (2015/16-2019/20), National Planning Commission (NPC), Ethiopia. p. 236.

https://europa.eu/capacity4dev/file/30510/

[42] El Bastawesy, M., Gabr, S. and Mohamed, I. (2015) Assessment of the Nile River's Hydrological Improvements as a Result of GERD Building. The Egyptian Journal of Remote Sensing and Space Science, 18, 65-75.

https://doi.org/10.1016/j.ejrs.2014.11.001

[43] Paisley, R.K. and Henshaw, T.W. (2013) Transboundary Governance of the Nile River Basin: Past, Present, and Future. Environmental Development, 7, 59-71. https://doi.org/10.1016/j.envdev.2013.05.003

[44] Melesse, A.M., Abtew, W. and Setegn, S.G. (2014) Nile River Basin: Ecohydrological Challenges, Climate Change and Hydropolitics. Springer Science \& Business Media. https://doi.org/10.1007/978-3-319-02720-3

[45] Goor, Q., Halleux, C., Mohamed, Y. and Tilmant, A. (2010) Optimal Operation of a Multipurpose Multi-Reservoir System in the Eastern Nile River Basin. Hydrology Earth System Science, 14, 1895-1908. https://doi.org/10.5194/hess-14-1895-2010

[46] Gebreluel, G. (2014) Ethiopia's GERD: Ending Africa's Oldest Geopolitical Rivalry? The Washington Quarterly, 37, 25-37. https://doi.org/10.1080/0163660X.2014.926207

[47] Tesfa, B. (2013) The Benefit of the GERD Project for Sudan and Egypt. Ethiopian International Professional Support for Abay, 1, 1-12.

[48] Zedan, B.A. (2014) Nile Water Conflict Management. Advanced Research in Engineering Sciences, 6, 18-36.

[49] Shahin, M. (2006) Hydrology and Water Resources of Africa. Springer Science \& Business Media, Dordrecht.

[50] Waterbury, W.D. and Jeuland, M. (2014) The GERD and the Eastern Nile's Cooperation Prospects. Water Policy, 16, 595-608. https://doi.org/10.2166/wp.2014.011b 